\title{
Policing through parody with Wellington Paranormal
}

\section{Erin Harrington}

English Department, University of Canterbury Te Whare Wānanga o Waitaha, Christchurch, Aotearoa New Zealand

Ph: +64 33694403

Email: erin.harrington@ canterbury.ac.nz

ORCID: 0000-0001-8584-4541

6217 words (main body) +840 words (references)

Erin Harrington is a lecturer in critical and cultural theory in the English department and Cultural Studies programme at the University of Canterbury. Her research looks at horror media, popular and visual culture, and gender and sexuality studies. 


\section{Policing through parody with Wellington Paranormal}

In late 2018, the New Zealand Police released a series of paranormal-themed road safety videos hosted by fictional Officers Minogue and O'Leary, the bumbling comic double act who helm the deadpan mockumentary series Wellington Paranormal (2018-). The Police's appropriation of these explicitly parodic characters here, as well as in promotional and recruitment material, is highly unusual. This is because Wellington Paranormal deftly mimics the representational and rhetorical strategies by which Police-sanctioned communications, such as the popular factual series Police Ten 7, use irony and understatement to manufacture a favourable image of the Police as stoic, reasonable, and good-humoured. However, the deadpan humour employed by Wellington Paranormal and Police Ten 7 operates on the basis of absence - of affect and of clear interpretive cues - which means that the inclusion of Officers O'Leary and Minogue in official Police communications represents a fascinating site of ideological contestation. This article argues that the multiple registers of mockumentary and deadpan humour open up a playful, transgressive space for satirical commentary that is not neutralised by the characters' co-option. As such, this article asks: to what extent might parodic materials become complicit in the power structures that they are critiquing, and where might the spectator sit within this dynamic?

Keywords: Wellington Paranormal; New Zealand Police; Police Ten 7; mockumentary; deadpan comedy.

\section{Introduction}

In December 2018, the New Zealand Police released what, at first, looked like a standard road safety announcement to its social media platforms. The minute-long video, 'Slow Down This Summer' (New Zealand Police 2018b) resembles an observational reality television show. Two uniformed officers, O’Leary and Minogue, address the camera as they conduct a mandatory traffic stop after pulling over a car that has been travelling at excessive speed. O'Leary explains that even on regular traffic 
duty, some situations quickly become paranormal, and Minogue states that sometimes drivers seem to become possessed. When Minogue leans down to talk to the unseen driver, a green, taloned hand shoots from the driver's window and grabs him round the throat. As the car's monstrous driver roars, O'Leary calmly indicates that she is heading back to her vehicle to get a cross and some holy water. The short closes back at the police station with Minogue and O'Leary speaking straight to camera, encouraging the viewer to take their time on the roads - to avoid becoming speed demons. However, Minogue has failed to adequately restrain the creature: it drags him off screen while O’Leary, annoyed, admonishes him for his persistent inability to follow procedure.

The two officers are, of course, not real members of the NZ Police: they are a bumbling, comic double act, played with deadpan precision by actors Mike Minogue and Karen O'Leary. The duo helm the horror-comedy mockumentary television series Wellington Paranormal (TVNZ 2018-), in which they investigate paranormal activity in and around New Zealand's capital city. They appear in three other road safety videos, which feature a zombie who needs a seatbelt, a ghostly drunk driver, and a distracting UFO. Each short closes with the official logos of the NZ Police and of Wellington Paranormal, the show, itself. Additionally Minogue and O'Leary feature in one of the NZ Police's elaborate viral recruitment videos as members of the force's 'real' secret paranormal division (New Zealand Police 2018a). This is indicative of the way that the characters have been swiftly and widely embraced in New Zealand; the actors make frequent in-character appearances across a range of news and entertainment media, and are even available for hire as event compères.

In this article, I argue that the relationship between Wellington Paranormal and its characters, and the NZ Police and its official communications, offers insight into how irony might serve a parodic or satirical agenda while also being commodified by 
those in power as a means of persuasion. There is a long history of crossover relationships between fictional broadcast media and official police interests, in which officers or organisations might act in an advisory capacity, or be more directly involved in production. Consider, for instance, the way that early American radio crime docudramas were endorsed by police and federal authorities as a means of improving their public image and persuading the public, rendering broadcast media another technology of policing (Battles 2010), just as the long-running American crime drama Dragnet, which transitioned from radio to television and film, was an explicit propagandistic vehicle for Los Angeles Police Department's priorities and perspectives (Sharrett 2012). This illustrates complex flows in power between media producers and products, which may gain significant benefits (such as access or a sense of authenticity) from official backing, and law enforcement organisations, whose authority, reach and image might be improved through positive affiliation with and representation in entertainment products.

By comparison, the NZ Police's partnership with explicitly parodic fictional officers is rare - and noteworthy. This is an important site of inquiry, for the NZ Police frequently and successfully use humour across their social media accounts; in 2016 the agency won the supreme award at the New Zealand Social Media Awards for instigating a viral, global ‘Running Man’ challenge (Police Media Centre 2016). Additionally, a number of New Zealand Government agencies and Crown entities, including the Human Rights Commission ('Give Nothing to Racism') and Tourism New Zealand ('Get New Zealand on Your Map'), have recently developed popular campaigns that incorporate deadpan humour and mockumentary tropes as a means of persuasion, just as the New Zealand Transport Agency has long used dry or absurd humour to communicate difficult topics in its varied road safety advertisements. This 
means that these paranormal road safety videos sit within a culturally specific constellation of officially sanctioned texts that leverage comic modes of address to bolster the authority and the social capital of official agencies.

As I will demonstrate, Wellington Paranormal uses the mockumentary form to both maintain and subvert expectations about New Zealand's extensive slate of policing reality shows, most notably the long-running Police Ten 7 (TVNZ 2002-), which is known for its tongue-in-cheek humour. I suggest that Wellington Paranormal exposes the Police's ideological agenda by deftly mimicking the representational and rhetorical strategies by which such shows manufacture a strategic image of the Police as stoic, reasonable, and good-humoured. Conversely, the Police's recuperation of these characters exploits humour as a means of soft power and social control, marking the agency as 'in on the joke' and in touch with the pop cultural zeitgeist. And yet, while Wellington Paranormal often leans towards the sort of apolitical, surface-level pastiche that Frederic Jameson termed 'blank parody', it can also be explicitly critical of the Police. Further, the deadpan humour employed by both Wellington Paranormal and Police Ten 7 operates on the basis of absence - of affect and of clear interpretive cues which prevents a stable reading. This means that the inclusion of Officers O'Leary and Minogue in official Police communications represents a fascinating site of ideological contestation, as well as slippery political and representational terrain. As such, this article asks: to what extent might satirical or ironic materials become complicit in the power structures that they are critiquing, and where might the spectator sit within this dynamic? 


\section{Wellington Paranormal's 'call to play'}

Wellington Paranormal is a spinoff of Taika Waititi and Jemaine Clements' droll 'slice of life' mockumentary What We Do in the Shadows (2014). The film, which is presented by the fictional New Zealand Documentary Board, follows a group of vampires who flat together in suburban Wellington. Officers O’Leary and Minogue are supporting characters who investigate a noise complaint at the vampires' house, and later attend the scene of a werewolf attack. In each instance, they are calm and professional but bland and unobservant to the point of idiocy. When they first visit the vampires, they fail to register that two of the flatmates are engaged in a hissing, mid-air fight, and that the charred remains of another lies in the basement. Instead, they point out the house's lack of working smoke alarms, which necessitates a 'bit of a dialogue' about safety. The running joke is whether their measured response is because of they have been inexpertly hypnotised by one of the vampires, or because they are, by nature, utterly oblivious.

Wellington Paranormal embraces this sense of knowing, deadpan absurdity. Minogue is well meaning, a little dim, and enthusiastic about Led Zeppelin and dad jokes. O'Leary, the more competent of the two, is level-headed, pragmatic and amiable. This characterisation is enriched by the viewer's potential knowledge that Karen O'Leary is not a trained actor; she works by day as an early childhood educator, and the fictional O'Leary speaks patiently to Minogue much as the real O'Leary might address her young charges. In the first episode, the two respond to an incident involving an ancient demon who attempts to open a 'hellmouth' in Cuba Street's bucket fountain - a kitschy kinetic sculpture that acts as an equally loved and maligned inner-city landmark. Afterwards, the pair are recruited by their superior, Sergeant Maaka (Maaka Pohatu), as the second and third members of his secret paranormal unit, which is based in a supply 
closet that is modelled after the basement office of The X-Files' Fox Mulder. The show leans into its debt to the paranormal drama. When the pair address the camera after their 'promotion', Minogue explains, ‘To put it in layman's terms we're kinda like Mulder and Scully. She's like Scully because she's analytical, she's got the brains, and I'm a man with brown hair' ('Demon Girl').

The series' comic engine is the juxtaposition of heightened supernatural action, which includes well-rendered special effects and character design, and the officers' lowkey, largely improvised responses, which aligns with the show's bland procedural style. In keeping with its progenitor's subversion of vampire narratives' Gothic Romanticism, each 'monster of the week' episode of Wellington Paranormal embraces, and undermines, well-established horror tropes. This first episode references The Exorcist (1973), and later episodes feature a variety of paranormal cases, including aliens that have been cloning farmers and putting cows up trees, zombified cops who set up breathtesting traffic stops to trap motorists, and a ghostly swingers' party that has generated 40 years' worth of noise complaints. Characters from What We Do in the Shadows make appearances, as do caricatures of local media personalities, such as a sham medium who is a clear nod to Australian Deb Webber, a 'real' psychic detective on the popular but controversial factual series Sensing Murder (TVNZ 2006-). These playful intertextual manoeuvres reward and exploit the audience's knowledge of the show's local and international cultural and cinematic contexts. This interplay between the horrific, the abject, and the ludicrous expands upon the original film's creation of an alternate Wellington - or its playful exposé of the 'real' Wellington.

Notably, Wellington Paranormal's use of deadpan humour, absurdity, understatement (including litotes), and situational irony is consistent with the key features of a stereotypically 'Kiwi' sense of humour (Gibson 2011; Harker 2013; Holm 
2017). Producer and writer Paul Yates noted during the series' promotion that 'New Zealanders tend not to go big when something big happens. If a meteorite landed in a Kiwi's backyard they'd be like, 'Oh yeah'... We think we've got that kind of little reaction and our two cops are very much that low-key, New Zealand kind of vibe' (Nealon 2018). The Chief Executive of funding agency New Zealand on Air, Jane Wrightson, similarly describes the series has having 'a unique New Zealand flavour' (Bevan 2018). This also aligns with the dominant tone of New Zealand horror films, which have largely privileged laughter and the grotesque over genuine terror or dread (Leotta 2010; Yeatman 2010). Wellington Paranormal's dry comedy fits clearly within a broader, self-congratulatory cultural paradigm that celebrates stoicism, practicality and 'just getting on with it' as positive national traits, even in the face of the unthinkable. Within the show's universe, the civic disorder caused by paranormal activity becomes a banal, everyday part of the city's fabric that is easily dealt to - for now, often ineffectually - with a stern telling off and a by-the-book safety warning. The Police's appropriation of the show's characters thus leverages a complex, self-reflexive sense of national cultural identity.

Additionally, Wellington Paranormal deploys the mockumentary form in a more complex manner than What We Do In the Shadows, which used its fly on the wall format as a narrative and comic strategy. Mockumentaries are complex, diverse texts that call attention to the ways that we construct and interpret factual discourse by appropriating documentary aesthetics in a reflexive manner. In doing so, they challenge the form's privileged cultural status by interrogating the language with which it constructs a sense of truthfulness, integrity and authority (Roscoe and Hight 2001). Craig Hight (2010) suggests that mockumentary is not just a form, but a discourse that is marked by dynamic flows between institutional practice, spectatorship and 
interpretation, and broader issues of referentiality, representation and textuality (15-17).

He argues that where the documentary's agenda is a 'call to action', the mockumentary's agenda is a 'call to play'. Whether a mockumentary is engaging in a serious metatextual critique, seeking to entertain, or attempting to mock or parody its subject matter, there is 'a point where audiences are intended to recognise and appreciate the fiction', which 'requires them to make continual assessments over what is real and what is not' (18). Within television mockumentaries, many of which lean towards comedy, the form might simply be an aesthetic or narrative choice (27). The mockumentary mode may also offer a politically reflexive interrogation of documentary as an institutional form that expresses 'unease with documentary pretentions' (33). This calls into question 'our often naive, immediate and common-sensical belief in the ability of the camera to accurately and objectively document the socio-historical work', which might in turn reveal 'documentary as simply another form of fiction' (33).

Mockumentaries thus ask us to enter into a contract with their creators, that we might come to believe in the veracity of the image, while simultaneously questioning the means by which belief is generated (Lipkin, Paget and Roscoe 2006, 18) - although this is contingent on us recognising the fiction in the first place. In Wellington Paranormal, we are asked to believe not only in the paranormal content that is caught, unromantically, on camera, but also the show's status as a 'real', Police-sanctioned reality series.

\section{Police Ten 7 and policing through parody}

Wellington Paranormal's key intertext is Police Ten 7, which launched in 2002 and recently completed its $26^{\text {th }}$ season. The observational series bills itself as 'New Zealand's only weekly crime fighting show', in which viewers can watch 'Police 
working on the frontline of crime... keeping our streets safe 24/7, 365 days of the year' ('Police Ten 7'). It is worth noting that New Zealand audiences have a pronounced appetite for series that partner with and promote the agendas of government and law enforcement agencies. Such shows vary in tone from tongue-in-cheek to manifestly punitive, and look variously at work undertaken by New Zealand Customs and Immigration services, government and military agencies involved in maritime rescue and law enforcement, police canine units, and specialist road policing units. ${ }^{1}$ These are joined by numerous similar series from Australia and the United Kingdom, to the extent that in 2015 the NZ Police's official Twitter account joked about the glut of 'cop shows' on television, using the hashtag \#allcopsallthetime ('Police Poke Fun'). Wellington Paranormal's relationship to Police Ten $7_{3}$ and the agency itself, is thus part of a complex arrangement of carceral cultural texts that are popular, persuasive, and selfaware.

Police Ten 7 owes a clear debt to the genre's progenitor, the long-running American series COPS (Fox 1989-2013; Spike / Paramount Network 2013-), in that it offers viewers an opportunity to 'ride along' with officers. COPS takes a gritty, cinema verité approach to its storytelling, emphasising the might and paramilitary capabilities of American law enforcement agencies. Its embrace of a law and order ideology suggests insistently that the 'thin blue line' is all that stands between civil society and chaos (Doyle 1998). Like comparable shows, Police Ten 7 uses formal and affective

\footnotetext{
${ }^{1}$ These include, but are not limited to, Border Patrol (TVNZ 2004-), Coastwatch (TVNZ 2010-), Dog Squad (TVNZ 2011-), Motorway Patrol (TVNZ 1999-), Highway Cops (TVNZ 2012-), Road Cops (Three 2010-) Serious Crash Unit (TVNZ 2004-15), Water Patrol (TVNZ 2014), and Nabbed (TVNZ 2014).
} 
strategies that explicitly align the audience with the police's perspective and mission (Cavender and Fishman 1998). The narration offered by show's original host, retired Detective Inspector Graham Bell, further emphasised this; Bell was known, and admired, for his gruff persona and colourful language, describing offenders, variously, as morons, creeps, bloody mongrels, stooges, half-wits, germs, low-lives and lunatic scumbags. Although it frames itself as a demystifying 'warts and all' account of everyday duties, Police Ten 7 over-represents exciting policework and does not reflect the significant amount of community policing and administrative duties undertaken by officers (Podvoiskis 2012). Instead, episodes feature in-car and on-foot pursuits, as well as instances of road and beat policing, many of which focus on disorderly behaviour. Hand-held material, filmed by crew, is augmented with footage from in-car and citywide surveillance cameras, which impart a sense of panoptic power. Episodes feature descriptions of active warrants and urgent appeals for public assistance, many of which are successful (Harvey 2017); as the show's current host, Detective Sergeant Rob Lemoto says forcefully in the show's opening credits, 'we need your help'.

Significantly, the show acts as an explicit recruitment tool: episodes frequently end with an officer describing why they joined the force, and directing viewers towards online recruitment materials.

The 'call to play' highlighted by Hight is apparent in the way that Wellington Paranormal appropriates Police Ten 7's form and style. Director of photography, DJ Stipsen has noted that the Wellington Paranormal was designed to fool an unsuspecting viewer into thinking that they were watching 'just another reality show about cops' ('Wellington Paranormal - Behind the Scenes - Cinematography'). The show's opening credits employ stylised red-on-blue animations laid over action-packed footage of paranormal call outs, workplace drama, and droll news headlines about mysterious 
suburban activity. Urgent synthesised theme music alludes to the themes Doctor Who and The X Files as much as it does other policing series. The ugly, no-frills aesthetics of reality series are replicated using natural lighting and limited artificial light sources, hand-held cameras operated by crew, remotely-operated mini-cameras mounted within police cars, and infrared body cameras worn by performers. Captions and time stamps overlay footage, and characters offer additional expository voice-over narration. Dramatic musical stings accompany action - or more often, a lack thereof. Additional scenes have the handheld, fly-on-the-wall style of workplace mockumentaries such as The Office. The episodes also borrow the narrative structure of reality series, beginning in media res as Minogue and O'Leary attend a call out, and ending with the pair offering wrap up narration to camera. Other design elements contribute to this sense of veracity, including specialist marked vehicles, canny adaptations of Police branding, and a slightly outdated Police uniform that lends a sense of shabby, fuzzy nostalgia. The Police's insignia has been also redesigned to include Wellington Harbour, a taniwha (a supernatural creature), and a moa (a giant, extinct flightless native bird), to gesture towards the city's paranormal leanings. These fine details connote a playful sense of 'reality'. Yet, in doing so, they also highlight the degree to which authentic documentarian language is itself carefully constructed to foster a sense of authoritative truthfulness by demonstrating how easy it is to manufacture signifiers of authority.

Wellington Paranormal's tone also calls attention to the way that Police Ten 7 employs deadpan humour. Unlike COPS, which could be best described as profoundly humourless, Police Ten 7 expresses pronounced tonal hybridity. In particular, it frequently features accounts of day-to-day policing that range from light and goodnatured to the outright bizarre. The show particularly relishes in the absurd antics provided by intoxicated individuals, much of which is (only just) bleeped out or 
pixelated for a pre-watershed audience, which offers the viewer the experience of slightly grotty prime-time schadenfreude. These sequences are contextualised humorously through dry, ironic voiceovers from the show's host, which position officers as long-suffering. This is emphasised in a short video released by producers Screentime New Zealand (2016) to mark the show's 500th episode. It acts not as a celebration of officers' crime-fighting successes, but as an audience-selected carnivalesque highlights reel of some of the show's most profane moments: bizarre acts of violence, rambling drunken monologues, instances of nudity and vulgarity, and some extremely creative swearing. It also features a viral clip from 2009 that inspired t-shirts, remixes and response videos, in which an officer offers a baffled car thief some deadpan safety advice: that to prevent burns from 'thermonuclear' late night service station pastries, you must 'always blow on the pie'. He finishes with the Police motto, 'safer communities together' ('Police Ten 7 (Always Blow on the Pie)').

It is beyond the scope of this article to make claims about the effectiveness of the NZ Police, although we must acknowledge that the producers of Police Ten 7 and its ilk align themselves, and by proxy the spectator, with the Police's ideological position. We must also assume that producers exclude portrayals of the Police that do not suit an official agenda as a matter of course. We can, however, compare specific representations of police in these shows to the strategic goals outlined by the New Zealand Police, especially in relation to the agency's aspirations regarding increased levels of positive public opinion and community engagement (New Zealand Police Citizens’ Satisfaction Survey 2018; New Zealand Police Four Year Plan 2017). Entertainment and news media representations of law enforcement and the justice system have demonstrable effects upon public perceptions of these institutions, police actions, and crime and criminality more generally. Positive television media 
representations of police and the foregrounding of law enforcement's perspectives are connected to positive attitudes towards the police as an entity; this includes perceptions of police use of force (Donovan and Klahm 2015), police effectiveness (Dowler 2002), and the police's moral authority (Cavender and Deutsch 2007). The New Zealand Ministry of Justice's Public Perception of Crime report (2016) also indicates that a third of their respondents saw reality television as one of the ways that they mainly heard about crime in New Zealand (18-20), highlighting the medium's importance.

I suggest that Police Ten 7's use of humour and irony must be seen as strategic, especially as it is a key element in the show's popularity and long-term success. The show's hybrid seriocomic tone, and its deliberate embrace of identifiably 'Kiwi' forms of deadpan humour and self-effacement, act as a means of relationship building and affective persuasion. Apart from appealing to viewers through humour, the show presents New Zealand Police officers as stoic, fair and good-natured: as patient, community-oriented negotiators who would prefer to de-escalate, and who are more interested in 'good outcomes' than punitive action, but who can be firm, and physical, if and when necessary. The cumulative impression of episodes of Police Ten 7 is also that of a metaphorical raised eyebrow to the audiences, as we are implicitly asked 'see what we have to deal with?'- a question that also shapes Minogue and O'Leary's encounters with the paranormal.

It is important to highlight that the NZ Police 'police by consent'. This means that their authority, outside of official and legal mandates, rests upon the trust, respect and support of the community; this is even stated outright by Minogue in the cold open of Wellington Paranormal's first episode. Unlike many of their international colleagues, most frontline police in New Zealand do not carry firearms on their person as a matter of routine, although they do carry non-lethal weapons, and have firearms available to 
them within their vehicles. (This becomes a running gag in Wellington Paranormal:

O'Leary and Minogue regularly bicker over whose week it is to carry the TASER, and Minogue seems incapable of wielding it without electrocuting himself.) New Zealand's unarmed constabulary, and its stated emphasis upon minimum force, are generally matters of public pride, although debate continues about the extent to which police should be armed (see Buttle 2010; Scott 2017). This necessitates engagement strategies that emphasise negotiation, relationship-building, and de-escalation - all strategies that New Zealand's policing series highlight, sometimes to comic or absurd effect, through the juxtaposition of individuals' anarchic behaviour and officers' calm, emotionally restrained responses. These are bolstered through the series' frequent use of humour as a narrative technique and affective strategy. This also means that criticisms of the Police - issues relating to excessive use of force, corruption, sexism, racism, homophobia, misconduct, accidents, under-resourcing, and high levels of attrition (see Edwards 2015) - can be framed within a complex media sphere as regrettable aberrations that are at odds with the Police's stated values (New Zealand Police Core Values and Competencies 2018), as opposed to symptoms of structural problems within the organisation. We must consider the inclusion of Wellington Paranormal's characters and humorous tone in official Police communications within this ideological context. It is offers an opportunity to build consent through humour, as well as a means of embracing and defusing potential criticism by being complicit in parodic representation and thus 'in on the joke', whatever that joke may end up being.

\section{Parody, satire and the politics of (deadpan) representation}

How, then, might we reconcile the relationship a parodic mockumentary, and its equally ironic source text? As Linda Hutcheon (2002) argues, postmodern 'parody 
works to foreground the politics of representation' (90, her emphasis). This is of particular note in instances where the relationship between the work (Wellington Paranormal) and that which is being cited (police-sanctioned factual series) might initially be read as skilful but 'empty': as frivolous, value-free mimicry, or 'mere' pastiche. The 'play' that Hight highlights can be very serious business indeed, for it acts as a 'contesting revision or rereading of the past that both confirms and subverts the power of the representations of history' (Hutcheon 2002, 91) through an interrogation of the assumptions we have about those representations. Hutcheon argues, 'Postmodern parody is both deconstructively critical and constructively creative, paradoxically making us aware of both the limits and the powers of representation' (94). This asks us to consider such parody as ironic and critical, and as opposed to the nostalgic and (neo)conservative recovery of the past offered by pastiche (94).

Deadpan humour's prevalence in both Wellington Paranormal and Police Ten 7 complicates this relationship considerably. Both series' dry characterisations open up a polysemous interpretive space that is as rich as it is treacherous, even when a preferred reading is flagged. In reality series, police officers' low-key reactions are coded as patient, professional and calm. Apart from its entertainment value to viewers, humour might offer first responders a brief moment of respite. As the 'blow on the pie' officer Sergeant Guy Baldwin notes, connecting with people through humour is an important way of moderating an 'unfunny' job ('Police Ten 7 (Always Blow on the Pie)'). As indicated, authorities also use humour as a means of soft power or persuasion, which is no less effective for its indirect manner. By contrast, the sincere, self-serious reactions of officers in Wellington Paranormal are signs of the characters' idiocy and lack of imagination. In the show's universe, institutions are completely ineffective. Sergeant Maaka's formal morning briefings resemble the notices given to a room full of 
schoolchildren, rather than insights into the region's policing. In the episode 'A Normal Night', he congratulates his officers for their swiftness in attempting to rescue a baby in distress from Wellington Harbour, even though it turned out to be a lost towel, while noting offhandedly the large number of unsolved murders in the area. O'Leary and Minogue have a childish rivalry with Officers Donovan and Laupepe, who are turned into zombies in the season one finale ('Zombie Cops'); their solution is to keep the two muzzled and assigned to 'zombie work' - chasing up fines on the phone. Minogue and O'Leary's laboured, routine-heavy discussions with suspects and witnesses demonstrate an inability to identify blatantly obvious issues of paranormal activity or criminality, even when it literally stares them in the face. Over the course of the first season, the pair lose their vehicle to a posse of creepy clowns, miss important information because they are too busy looking at pictures of cute animals on social media, and at one point quietly hope that they might get to witness a gangland shoot out.

Notably, where we share the authoritative, ideological position of the police in official reality series, here we implicitly share the position of the ever-present, allseeing crew, whose role is more ambivalent. Deadpan situational irony is a key component of the show's comic language: we see that Minogue and O'Leary have been hypnotised by a vampire, that the ghosts they've released from a decades'-long swingers' party are actually being sent to hell, and that cloned alien versions of themselves are stumbling off to terrorise the countryside. This positions our gaze as documentarian but inherently critical; the police are the object, and not the bearer of the look. The pair frequently invoke the NZ Police's motto, 'safer communities together', which asks, teasingly, who do communities need to be saved from, and who can we trust to do this? 
We must also consider the teasing slippage between parody and satire; both use irony, but satire is 'extramural' (Hutcheon 1985, 43), targeted outwards, and more pejorative and negative in nature (Hutcheon 1985, 56). I suggest that one target for the show's satire is the viewer, and our collective enthusiasm for cultural products that promote and sanction the perspectives of official bodies, including repressive, coercive agencies that have a mandate to exercise violence, control and privation. In New Zealand, official agencies have commodified irony to the point where it is utterly mainstream. Mockumentary has become as institutional a form as documentary itself, which asks us to consider the extent to which a parodic work, or the reader interpreting it, might be complicit in its appropriation.

This poses something of a problem when teasing apart a work's politics (Hutcheon 1995 11-12; 41-2), for deadpan's lack of interpretive cues also supports 'the prevention of closure' (Holm 2017, 108). Additionally, when we attempt to interpret ironic work there tends to be a focus on the intention of irony on the part of the creator. Yet, it is the reader who attends to the work's semantic and evaluative inferences - the interaction of the said and the unsaid. As such, deadpan can be understood not just as a muted form of humour but also as an 'intentionally elusive one, one that always threatens to withdraw its status as humour and thereby leave the laughing audience high and dry, laughing at a joke that is not really there' (Holm 2017, 108).

We see these complex power dynamics in some of Wellington Paranormal's darker comic moments. The show can be cutting, highlighting systemic abuses of power, which complicates the Police's use of its characters in official communications. In 'A Normal Night' Minogue breaks a blood bag on himself, and loudly announces to hospital staff and visitors that he and O'Leary 'definitely' haven't been 'brutalising' anyone, much to O'Leary's embarrassment. The implication is that the public's 
suspicions might, historically, be well-founded. At the end of the same episode the lowkey vampire Nick, who we first meet in What We Do in the Shadows, complains to the camera crew that he's been arrested because of racial profiling: '[It's j]ust because I'm a brown vampire walking through a cemetery'. Although he's patently guilty of stealing blood bags - he likens them to Juicies, a frozen juice product long popular in school tuck shops - this has the ring of truth. Nick is ethnically ambiguous, heavily tattooed, and dressed in black; he clearly fits a racial stereotype. Comparatively, a yellow-eyed Nosferatu-lookalike named Alexandr, who is lurking in the cemetery in outrageous gothic garb, is interviewed by the camera crew as a credible witness. This absurdity illustrates the fact that Police Ten 7 is known to over-represent Māori and Pacific Island offenders and under-represent white offenders (Podvoiskis 2012, 88-90). Here, Eurocentric monsters are considered far less a problem than ordinary-looking people of colour by the police, the crew, and potentially the viewer.

The second, reciprocal argument is that we may look for humour in blank spaces where none is present. The first season's most troublesome interaction comes in the episode 'The She-wolf of Kurimarama Street', which centres on the carnage caused by a woman, who is coded as 'trashy', boorish and lower class, who has recently become a werewolf. ${ }^{2}$ At the end of the episode, she confronts her ex-boyfriend, who she blames for her transformation; lycanthropy is compared to a sexually transmissible infection, with the concomitant inference of unsafe and irresponsible sexual practices. The two begin to have rough sex, or perhaps they are attacking one another, or both; from the street, looking at the shadows on the curtains, it appears as if a violent assault is taking

\footnotetext{
2 'Kurimarama' is a portmanteau of the Te Reo Māori words for dog (kurī) and moon (marama).
} 
place. O'Leary and Minogue, speak uneasily to camera, attempting to maintain the measured, authoritative tone we expect of Police Ten 7. They clearly wish to mark the escalating situation as 'resolved'; they know, and we know, that we have hit the end of the episode, so things are going to be wrapped up one way or another. They state that this is now a 'personal issue', congratulate themselves uncertainly on a job well done, and finish again with the Police motto, 'safer communities together', an aspirational phrase that now seems glib and empty.

The episode flippantly invokes the way that New Zealand's horrendous rates of family violence, which are a matter of public shame, are often dismissed euphemistically as 'domestics' - within the world of the show, by the police in general, and through its use, within a cultural text, as a comic punchline. The use of such bleak humour creates further dissonance within our interpretation of the Police's appropriation of the show and its characters; this is, at face value, too critical of the Police to be cheerily recuperated. This also offers a difficult point of encounter with Police Ten 7's audience-selected 'greatest hits' reel. If it is not humorously abject, then is a tragic indictment of our collective national 'she'll be right' inability (and perhaps unwillingness) to deal with serious social harm and pain. Nonetheless, there is still scope for a convenient protestation of innocence, that it's 'just a joke', which tips power easily back towards authority. Crime in New Zealand disproportionally affects a small number of people; the 2018 New Zealand Crime and Victims Survey indicates that $4 \%$ of adults experience $47 \%$ of all crime (100). This makes it easy to 'other' victims as well as perpetrators, to dehumanise them as the butt of a joke, be they on a fictional comedy or a reality series.

A third target, though, its officialdom itself, and I suggest that this is where Wellington Paranormal is its most quietly subversive. Actor Karen O’Leary has a 
remarkable ability to calmly ad-lib streams of empty, clichéd jargon and procedural descriptions to camera, even while under duress. In the episode 'Demon Girl', O'Leary becomes stuck while attempting to scale a fence during the pursuit of a possessed housewife. As she dangles by her trousers she speaks calmly straight to camera: Well, obviously, you do get hurdles in policing and, um, these sorts of fences are certainly, ah, one of them, you know it's a real challenge, um, I think certainly since they changed the way they make these fences it's been a lot harder to get over them cleanly, um, it's not something that normally happens to me, to be honest, if anything Minogue perhaps is a little bit more prone to this kinda thing, but like I said I was just giving it my best shot and it didn't quite work out on the day...

Such torrents of comic, vacuous nonsense are the series' linchpin; they structure much of the series' semi-improvised dialogue, and Wellington Paranormal would not work without them. They also deconstruct, elegantly, the way that the empty, dishonest 'bullshit' of officialdom and managerialism comes to stand in for true communication by being naturalised as a form of authoritative speech, whether it is being deployed by sportspeople, politicians, businesspeople, or agencies such as the Police themselves. Wellington Paranormal thus slips uneasily between affectionate pastiche and self-reflexive critique. As a deadpan, parodic text, it confronts the viewer with contradictory interpretive cues. The NZ Police's appropriation of these characters in official communications and recruitment media does not eliminate these rich interpretive spaces; it merely renders them even more complex. This is because, as Nicholas Holm (2017) suggests, 'The aesthetic withdrawal that characterises deadpan ... threaten[s] to make it difficult if not impossible to conceive of the politics of deadpan comedy' (118-9). Its restraint 'thus undermines the equation of humour with a 
politics of challenge and, through its pronounced disengagement, shies away from any broad claim to political efficacy' by tilting towards indirectness and even apology (119). This also means that deadpan humour cannot be truly co-opted, even within a cultural environment that embraces authoritarian and punitive media or that positions mockumentary as an authoritative mode of address, including by agencies with great civic or coercive power. Importantly, this polysemy creates space in terms of reception, especially within a cultural space - New Zealand comedy and television, and media culture more generally - in which viewers are highly literate in interpreting (or at least doing things with) deadpan comedy. As such, official agencies' commodification of irony can never be closed or complete. It always rests on the viewers' willingness to embrace, or reject, both a text's call to play and its effacement of politics.

The New Zealand Police's paranormal road safety videos thus act as a fascinating site of ideological contestation, and a provocative site of interpretive slippage. They highlight how the agency chooses to police through parody, by making affectionate use of well-loved characters and multiple, intertextual comic registers, and by deploying humour as an affective and effective tool of persuasion across its media products. Participating in the joke, after all, is a great way for those in power to attempt to neutralise potential critique. But these videos act as a delicate and perhaps ideologically treacherous exemplar, by calling attention to the ways that official institutions might commodify irony. In doing so, these texts implicitly invite us to question our own complicity with power within these transactions, and to interrogate the ways we may engage with parody and satire across multiple, and contradictory, popular contexts.

\section{Acknowledgements}


Many thanks to Nicholas Wright for his invaluable comments on an earlier version of this project. Thanks also to the editor and the reviewers for their generous and insightful feedback.

\section{Declaration of interest statement}

There are no conflicts of interest.

\section{References}

'A Normal Night'. 2018. Wellington Paranormal. Directed by Sam Smith. Aired 8 August, TVNZ2.

Battles, Kathleen. 2010. Calling All Cars: Radio Dragnets and the Technology of Policing. Minneapolis: University of Minnesota Press.

Bevan, Darren. 2018. '13 new episodes of Wellington Paranormal will air in 2019'. Stuff, October 3. https://www.stuff.co.nz/entertainment/tv-radio/107570384/13-newepisodes-of-wellington-paranormal-will-air-in-2019.

Buttle, John. 2010. 'The Case Against Arming the New Zealand Police'. Academia.edu. https://www.academia.edu/395156/The_Case_Against_Arming_The_New_Zealand_Po lice.

Cavender, Gray and Sarah K. Deutsch. 2007. 'CSI and moral authority: The police and science'. Crime, Media, Culture: An International Journal 3 (1): 67-81. 
Cavender, Gray and Mark Fishman. 1998. 'Television Reality Crime Programs: Context and History'. In Entertaining Crime: Television Reality Programs, edited by Mark Fishman and Gray Cavender, 1-17. New York: Aldine de Gruyter.

'Demon Girl'. 2018. Wellington Paranormal. Directed by Jemaine Clement and Paul Yates. Aired 11 July, on TVNZ2.

Donovan, Kathleen M., and Charles F. Klahm. 2015. 'The Role of Entertainment Media in Perceptions of Police Use of Force'. Criminal Justice and Behavior 42 (12): 126181.

Dowler, Kenneth. 2002. 'Media Influence on Citizen Attitudes Toward Police Effectiveness'. Policing and Society: An International Journal of Research and Policy 12 (3): $227-238$.

Doyle, Aaron. 1998. “Cops": Television Policing as Policing Reality’. In Entertaining Crime: Television Reality Programs, edited by Mark Fishman and Gray Cavender, 95116. New York: Aldine de Gruyter.

Edwards, Bryce. 2015. 'NZ Police are failing the public'. New Zealand Herald, April 5. https://www.nzherald.co.nz/nz/news/article.cfm?c_id=1\&objectid=11427914. 
Get New Zealand On Your Map. Tourism New Zealand.

https://www.newzealand.com/int/feature/get-new-zealand-on-the-map/. Accessed 10 June 2019.

Gibson, Andy. 2011. 'Flight of the Conchords: Recontextualizing the Voices of Popular Culture'. Journal of Sociolinguistics 15 (5): 603-26.

Give Nothing to Racism. Human Rights Commission. https://givenothing.co.nz/. Accessed 10 June 2019

Harker, Catherine. 2013. 'Humour'. Te Ara - the Encylopedia of New Zealand. https://teara.govt.nz/en/humour.

Harvey, Kerry. 2017. "Police Ten 7 producer Sarah-Luise Whatford says Kiwis love to help the police". Stuff, 26 February. https://www.stuff.co.nz/entertainment/tvradio/89628717/police-ten-7-producer-sarahluise-whatford-says-kiwis-love-to-help-thepolice.

Hight, Craig. 2010. Television Mockumentary: Reflexivity, Satire and a Call to Play. Manchester, UK; New York, NY: Manchester University Press.

Holm, Nicholas. 2017. 'The Politics of Deadpan in Australasian Satire'. In Satire and Politics: The Interplay of Heritage and Practice, edited by Jessica Milner Davis, 10324. New York, NY: Springer Berlin Heidelberg. 
Hutcheon, Linda. 1985. A Theory of Parody: The Teachings of Twentieth-Century Art Forms. New York: Methuen.

Hutcheon, Linda 1995. Irony's Edge: The Theory and Politics of Irony. London ; New York: Routledge.

Hutcheon, Linda. 2002. The Politics of Postmodernism. 2nd ed. London ; New York: Routledge.

Leotta, Alfio. 2010. 'From Comic-Gothic to "Splatstick": Black Humour in New Zealand Cinema'. In Directory of World Cinema: Australia and New Zealand, edited by Ben Goldsmith and Geoff Lealand, 296-303. Intellect Ltd.

Lipkin, Steven N., Derek Paget, and Jane Roscoe. 2006. 'Docudrama and MockDocumentary: Defining Terms, Proposing Canons'. In Docufictions: Essays on the Intersection of Documentary and Fictional Filmmaking, edited by Gary Don Rhodes and John Parris Springer, 11-26. Jefferson, N.C: McFarland \& Co.

Nealon, Sarah. 2018. "Wellington Paranormal takes up What We Do In the Shadows' comedy mantle". Stuff, 29 June. https://www.stuff.co.nz/entertainment/tvradio/105041801/a-what-we-do-in-the-shadows-spinoff-is-finally-here.

New Zealand Crime and Victims Survey: Key Findings Cycle 1 (March-September 2018). 2019. Ministry of Justice. 
https://www.justice.govt.nz/assets/Documents/Publications/NZCVS-A4-KeyFindings2018-fin-v1.1.pdf.

New Zealand Police. 2018a. “"Breaking News” New Zealand Police release EPIC new recruitment video'. Facebook, 28 October.

https://www.facebook.com/NZPolice/videos/2237951626475719/.

New Zealand Police. 2018b. "Slow down this summer." Facebook, 20 December. https://www.facebook.com/NZPolice/videos/657921548007420/.

New Zealand Police Citizens' Satisfaction Survey: Report for 2017/18. 2018. New Zealand Police. https://www.police.govt.nz/sites/default/files/publications/citizensatisfaction-survey-report-2018.pdf.

New Zealand Police Core Values and Competencies. 2018. New Zealand Police. https://www.police.govt.nz/about-us/publication/new-zealand-police-core-values-andcompetencies.

New Zealand Police Four Year Plan (2107/2018 - 2020/2021). 2017. New Zealand Police. https://www.police.govt.nz/sites/default/files/publications/2017-21-police-fouryear-plan.pdf.

Podvoiskis, Gabrielle. 2012. Reel Cops: Exploring the Representation of Policing on Police Ten 7. Masters thesis, Victoria University of Wellington. http://researcharchive.vuw.ac.nz/handle/10063/2458. 
Police Media Centre. 2016. 'NZ Police "Running Man” video wins social media award'. New Zealand Police, 18 August. https://www.police.govt.nz/news/release/nzpolice-running-man-video-wins-social-media-award

'Police poke fun at TV3 Road Cops programming'. 2015. Stuff, June 3. https://www.stuff.co.nz/entertainment/tv-radio/69064330/.

'Police Ten 7'. Screentime New Zealand. Accessed 31 May, 2019. https://www.screentimenz.com/police-ten-7.

'Police Ten 7 (Always Blow on the Pie)'. NZ On Screen. Accessed 31 May 2019. https://www.nzonscreen.com/title/police-ten-7-always-blow-on-the-pie-2009.

Public Perceptions of Crime 2016 - Survey Report. 2016. Ministry of Justice. https://www.justice.govt.nz/assets/Documents/Publications/20161130-Final-PPSreport.pdf.

Roscoe, Jane, and Craig Hight. 2001. Faking It: Mock-Documentary and the Subversion of Factuality. Manchester ; New York : New York: Manchester University Press.

Scott, Mark. 2017. 'Force to be reckoned with: The myth of our unarmed police'. Noted. https://www.noted.co.nz/currently/social-issues/force-to-be-reckoned-with-themyth-of-our-unarmed-police/. 
Screentime NZ. 2016. 'Police Ten 7 ‘500 Episodes'. YouTube, 23 June.

https://www.youtube.com/watch?v=vLhYsRdl3H4.

Sharrett, Christopher. 2012. 'Jack Webb Right-Wing and the Vagaries of TV

Entertainment'. Cinema Journal 51 (4): 165-171.

'The She Wolf of Kurimarama Street'. 2018. Wellington Paranormal. Directed by Jessica Hansell. Aired 1 August, TVNZ2.

'Wellington Paranormal - Behinds the Scenes - Cinematography'. 2018. 1 August, TVNZ OnDemand. https://www.tvnz.co.nz/shows/wellingtonparanormal/episodes/behind-the-scenes-cinematography.

What We Do in the Shadows, directed by Taika Waititi and Jemaine Clements.

Melbourne, Australia: Madman Entertainment, 2014.

Yeatman, Bevan. 2010. 'Horror in New Zealand: A Quivering of Borders'. In Directory of World Cinema: Australia and New Zealand, edited by Ben Goldsmith and Geoff Lealand, 310-13. Intellect Ltd.

'Zombie Cops'. 2018. Wellington Paranormal. Directed by Jemaine Clement and Paul Yates. Aired 15 August, TVNZ2. 